\title{
Optimization of Total Carotenoid Production by Halorubrum Sp. TBZ126 Using Response Surface Methodology
}

\author{
Masoud Hamidi ${ }^{1,2}$, Malik Zainul Abdin ${ }^{3}$, Hossein Nazemyieh', Mohammad Amin Hejazi ${ }^{4 *}$ and Mohammad Saeid Hejazi ${ }^{1,5 *}$ \\ ${ }^{1}$ Faculty of Pharmacy, Tabriz University of Medical Sciences, Tabriz, Iran \\ ${ }^{2}$ Students' Research Committee, Tabriz University of Medical Sciences, Tabriz, Iran \\ ${ }^{3}$ Centre for Transgenic Plant Development, Department of Biotechnology, Faculty of Science, Jamia Hamdard (Hamdard University), New Delhi, India \\ ${ }^{4}$ West and Northwest Agricultural Biotechnology Research Institute of Iran (ABRII), Iran \\ ${ }^{5}$ Faculty of Advanced Biomedical Sciences, Tabriz University of Medical Sciences, Tabriz, Iran
}

\begin{abstract}
Carotenoids are one of the most diverse and broadly distributed classes of pigments in nature with a high number of biotechnological applications. Carotenoids have a broad range of functions, especially in relation to human health and their role as biological antioxidants. The increasing demand for consumption of natural carotenoids has raised interest in their bio-production. The objective of the present study was the analysis of environmental factors (temperature, $\mathrm{pH}$ and salinity) through response surface methodology (RSM) on the total carotenoid production of Halorubrum sp. TBZ126. In addition the effect of light was evaluated. Five levels of temperature, $\mathrm{pH}$, and salinity were selected based on central composite design (CCD) and RSM to reach the optimum values for the cell growth and carotenoid production. Bio-production was carried out in an orbital shaker using a 10\% (v/v) inoculum, and agitation at $120 \mathrm{rpm}$ for 9 days in a non-illuminated environment. Dry cell weight was determined and total carotenoid was estimated by spectrophotometer. The production of biomass ranged from 0.04 to $0.84 \mathrm{~g} / \mathrm{l}$ and the total carotenoid from 0.15 to $10.78 \mathrm{mg} / \mathrm{l}$. The optimum conditions for cell growth and total carotenoid production in Halorubrum sp. TBZ126 cultures, were temperature $31^{\circ} \mathrm{C}$ and $32^{\circ} \mathrm{C}, \mathrm{pH} 7.51$ and 7.94 and $\mathrm{NaCl}(\mathrm{w} / \mathrm{v}) 18.33 \%$ and $20.55 \%$, respectively. In conclusion, employing RSM design and under the light exposure as an inducing factor, carotenoid production by Halorubrum sp. TBZ126 was elevated by $45 \%$. Additionally, TBZ126 could produce carotenoids at lower concentrations of $\mathrm{NaCl}$ (as low as 2.5\%), in the absence of sodium acetate without elevating magnesium sulfate concentration.
\end{abstract}

Keywords: Carotenoid; Halorubrum; Light; Optimization; Salinity; Temperature

\section{Introduction}

Carotenoids are natural pigments synthesized by bacteria, fungi, algae, and plants, and more than 750 different carotenoids have been isolated from natural sources [1]. These pigments are generally hydrophobic compounds which will therefore have a tendency to be associated with lipid or in hydrophobic structure such as membranes. Animals cannot synthesize carotenoids, so their presence is due to dietary intake [2]. Carotenoids are important as nutraceutical compounds and natural lipophilic antioxidants. The antioxidative potential of carotenoids depends on their chemical properties, such as the number of conjugated double bonds, structural end groups, and oxygen-containing substituents [3].

The demand and market for carotenoids is anticipated to change with the discovery that carotenoids exhibit tumor suppressing activity and play an important role in the prevention of chronic diseases. In addition to their antioxidant properties, a number of unexpected biological effects of carotenoids, for example, in junctional communication and gene regulation, have been recently discovered and attributed to their tumor suppressing activity boosting the interest in evaluating the pharmaceutical potential of carotenoids [4]. The commercial demand of carotenoids is mainly met by chemical synthesis and to a minor extent by extraction from natural sources [3]. Food (i.e., plants or food processing wastes) and microorganisms are examples of carotenoids' natural sources. Unlike microorganisms, the production of carotenoids from food has many disadvantages, such as season fluctuation, limited resources, competition with the food industry, and requirement of land beside complicated extraction and purification process. For instance, the carotenoids produced from plants contain mixtures of carotenoids, fats, oils, waxes, and unsaponifiable compounds. Microbial carotenoids are cell-bound pigments that are produced inside the cells and do not diffuse in the agar. Carotenoids give the microbial colonies their distinctive color (i.e., yellow, orange, pink, or red) [5].

Several algae (Dunaliella, Dictyococcus and Haematococcus), bacteria (many species of eubacteria in addition to halobacteria in archaebacteria), some filamentous fungi (belong to lower fungi and Ascomycetes) and yeasts (Cryptococcus, Phaffia, Rhodosporidium, Rhodotorula, Sporidiobolus, and Sporobolomyces) are reported to produce carotenoids [6]. Nevertheless, the microbial production of carotenoids is still awaiting lot of challenges to reduce cost and simultaneously increase productivity possibly by increasing biomass production and/or carotenoid synthesis, for example by selecting a strain that grows fast, accumulates high amount of carotenoids, facilitates the extraction and purification processes of carotenoids, and has a lower cost production [5].

*Corresponding authors: Mohammad Saeid Hejazi, Faculty of Pharmacy, Tabriz University of Medical Sciences, Tabriz, Iran, Tel: +98 (411) 337 2256; Fax: +98 (411) 334 4798; E-mail: msaeidhejazi@yahoo.com, saeidhejazi@tbzmed.ac.ir

Mohammad Amin Hejazi, West \& Northwest Agricultural Biotechnology Research Institute of Iran (ABRII), Tabriz, Iran, Tel: +98 (411) 5156915-598; Fax: +98 (411) 3321615; Email: aminhejazi@yahoo.com

Received April 17, 2014; Accepted June 16, 2014; Published June 23, 2014

Citation: Hamidi M, Abdin MZ, Nazemyieh H, Hejazi MA, Hejazi MS (2014) Optimization of Total Carotenoid Production by Halorubrum Sp. TBZ126 Using Response Surface Methodology. J Microb Biochem Technol 6: 286-294. doi:10.4172/1948-5948.1000158

Copyright: ( 2014 Hamidi M, et al. This is an open-access article distributed under the terms of the Creative Commons Attribution License, which permits unrestricted use, distribution, and reproduction in any medium, provided the original author and source are credited 
Microorganisms classified under the domain archaea are gaining tremendous attention for their ecological distribution, biochemistry, physiology, molecular biology and biotechnological applications [7]. Among the three major groups of archaea, i.e., the methanogens, the thermophilic sulfur utilizers, and the extreme halophiles, the latter group has the most metabolic diversity [8]. Most of halophilic archaea in the family of Halobacteriaceae are brightly red-orange because of their red membrane consisting of carotenoid pigments [9]. The pinkred color of the hypersaline environments is caused by bacterioruberin and other bacterioruberin derivatives present in the family of Halobacteriaceae and also $\beta$-carotene derived from Dunaliella salina $[10,11]$.

Among the red-colored metabolites of extremely halophilic archaea, bacterioruberin is considered the major component of the $\mathrm{C}_{50}$ carotenoids. Bacterioruberin is known to contain 13 pairs of conjugated double carbon bonds, endowing biological tissues with effective hydroxyl free-radical scavenger power and singlet oxygen quenching activity. This pigment can protect Halobacteria from fatal injuries under intensive light and confers bacteria with resistance to oxidative DNA damage from radiography, UV-irradiation, and $\mathrm{H}_{2} \mathrm{O}_{2}$ exposure. Bacterioruberin also has other equally important roles for membrane fluidity, including its function as a water barrier and responsibility for the permeability of oxygen and other molecules, thus enhancing bacterial survival in hypersaline and low-temperature environments [12].

According to the literature, the types of carotenoids and their relative amount may vary depending on the cultivation medium, temperature, $\mathrm{pH}$, salinity (for halophilic (micro) organisms), rate of aeration, luminosity, inductors chemical agents and so on [13-20]. Thus, the development of optimization studies regarding the effect of temperature, $\mathrm{pH}$ and salinity on the production of carotenoids is necessary to reduce costs and improve yields [21]. Indeed it is necessary to understand both the factors that determine the most efficient cell growth and those that determine maximum carotenoid production. Many studies have been undertaken to evaluate conditions for optimal carotenoid production, however, it is not possible to draw general conditions. Therefore conditions must be determined for each individual microorganism [22]. To our knowledge, there is no report regarding optimization of growth condition and carotenoid production by Halorubrum sp. TBZ126 and Halorubrum chaoviator as the most closely genetically related archaeon to it.

The main problem with the one-factor-at-a-time approach is that possible interactions between factors will go unnoticed, when in reality, interactions between factors are very common and important. Statistical experimental methods such as full or fractional factorial designs, central composite design (CCD), and response surface methodology (RSM) can be used in microbial processes to determine the main effects and interactions of the factors that play basic roles in the fermentation processes. On the other hand, RSM, a collection of statistical methods, is a useful tool that can be used to construct the model, design and test the trials, seek and optimize the significant factors, identify the optimum conditions, and establish the numerical correlations for the target responses. RSM has been successfully applied in various fields such as food manufacturing processes, medium composition and fermentation conditions. In recent years, these statistical design methods have also been applied to screen out and optimize the significant factors for carotenoid production by carotenogenic microbes. Also, various statistical experimental designs for optimization of fermentation parameters may allow more efficient and more economical carotenoid biosynthesis via microbial fermentations [23].
In the present work, following our previous study about identification of an extremely halophilic archeon, Halorubrum sp. TBZ126 from Urmia Lake and analysis of its carotenoid profile [24], we aimed to optimize the culture conditions for both cell growth and total carotenoid production by Halorubrum sp. TBZ126. For this purpose, a statistical experimental design was employed rather than the one-factor-at-a-time approach. Therefore, the effects of various factors including temperature, $\mathrm{pH}$ and salinity could be simultaneously investigated. In addition the effect of light on cell growth and total carotenoid production in optimized condition was evaluated. The strain under study (Halorubrum sp. TBZ126) and Halorubrum chaoviator, the most closely genetically related archaeon to it, have not been studied before regarding to optimization of their cell growth and carotenoid production.

\section{Materials and Methods}

\section{Microorganism}

Halorubrum sp. TBZ126, an extremely halophilic archaeon isolated from Urmia Lake described previously [24], was employed in this study.

\section{Experimental design and process optimization}

CCD methodology was exploited to optimize the culture conditions for both cell growth and total carotenoid production by Halorubrum sp. TBZ126. A $2^{3}$ factorial experimental design with 6 replicates at the center point and 6 axial points, thus a total of 20 experiments was conducted. The center point replicates were selected to verify any change in the assessment procedure, as a measure of exactitude property. The basal medium (marine broth [24]) was prepared with 15 combinations of the independent variables ( $\mathrm{pH}$ and salinity). Five levels of temperature, $\mathrm{pH}$ and salinity were selected to reach the optimum values for the cell growth and carotenoid production. These values were: temperatures $15,22,32.5,43$, and $50^{\circ} \mathrm{C}$ (levels $-1.68,-1$, 0,1 , and 1.68 respectively), $\mathrm{pH}$ values of $4,5.2,7,8.7$, and 10 (levels $-1.68,-1,0,1$, and 1.68 respectively), and salinities (\% $\mathrm{w} / \mathrm{v}$ of $\mathrm{NaCl}) 2.5$, $8.8,16.25,24$, and 30 (levels $-1.68,-1,0,1$, and 1.68 respectively). The experimental results of the central composite design were fitted with a second-order polynomial equation by a multiple regression technique. The quality of fit of the second-order model equation was expressed by the coefficient of determination $R^{2}$ and its statistical significance was determined by $p$-value. The response or dependent variables studied were total carotenoids $(\mathrm{mg} / \mathrm{l})$, cell mass $(\mathrm{g} / \mathrm{l})$ and carotenoid production as $\mathrm{mg} / \mathrm{g}$.

\section{Preparation of inoculum}

The 6 days old culture, at the logarithmic stage of growth, having an optical density $(600 \mathrm{~nm})$ of 0.65 , was used as the inoculum in all experiments. These cultures were used as inoculum at $10 \%(\mathrm{v} / \mathrm{v})$ for all the experiments.

\section{Culture conditions}

The marine broth [24] was prepared with 15 combinations of the independent variables ( $\mathrm{pH}$ and salinity). All experiments were conducted in $250 \mathrm{ml}$ erlenmeyer flasks containing $90 \mathrm{ml}$ of the growth medium. After inoculation, the flasks were incubated with shaking at $120 \mathrm{rpm}$ in dark for 9 days. It is noteworthy that dissolved oxygen availability cannot be evaluated in shake flask cultivation systems. Additionally, Debelius and colleagues measured oxygen solubility in natural samples with salinity values ranging from $0 \%$ to $133 \%$ and 
temperatures ranging from 8 to $35^{\circ} \mathrm{C}$. They concluded that for salinity values of less than $40 \%$, variation in oxygen availability is minor [25].

\section{Growth curve and determination of cell mass}

As time is an independent variable and must be kept fixed in all experiments, determination a fixed time for the trials was done by drawing growth curve of Halorubrum sp. TBZ126 growth in general condition (temperature $30^{\circ} \mathrm{C}, \mathrm{pH} 7.5$ and $25 \%$ salinity) that performed in our previous paper [24]. Therefore aliquots $(1 \mathrm{ml})$ of the cultures were used to measure growth in terms of optical density (O.D.) at $600 \mathrm{~nm}$ of samples withdrawn aseptically from the flasks, with a spectrophotometer (Shimadzu UV-1800 Series, Kyoto, Japan). The experiment was carried out in triplicate.

Cell mass [dry cell weight (g DCW/l)] was determined as described previously [26,27]; $1 \mathrm{ml}$ of culture sample in a pre-weighed tube centrifuged at 10,000 rpm for 5 min by the Beckman Coulter Allegra $\mathrm{X}-22 \mathrm{R}$ centrifuge. The supernatant was removed, the cells were washed with saline $1 \%$ and dry cell weight was measured by drying the wet pellet to a constant weight in an $80^{\circ} \mathrm{C}$ oven.

\section{Pigments extraction and analysis}

The extraction of carotenoids from the cell and determination of total carotenoids (spectrophotometrically) have been already described in our previous work [24]. In brief, $100 \mathrm{ml}$ of marine broth cultures were centrifuged at $8,000 \mathrm{rpm}$ for $10 \mathrm{~min}$ at $4^{\circ} \mathrm{C}$. The supernatant was separated and a mixture of acetone-methanol (7:3 v/v) [21] containing butylhydroxytoluene (BHT) $(0.1 \%$; as antioxidant) was added to the pellet. The pelleted cells were then frozen and thawed using liquid nitrogen to facilitate extraction and followed by centrifugation at $10,000 \times \mathrm{g}$ for $10 \mathrm{~min}$ at $4^{\circ} \mathrm{C}$. Successive extractions carried out until both solvent and cells were colorless. The solvent was evaporated under a stream of nitrogen and the pigments were dissolved in 10 $\mathrm{ml}$ of acetone (containing $0.1 \%$ BHT). Samples were wrapped with aluminum foil to protect them from light. Extraction solution UVVIS spectra were recorded at $200-700 \mathrm{~nm}$ using a spectrophotometer (Shimadzu UV-1800 Series, Kyoto, Japan). The approximate content of total carotenoids was according to the formula described previously [24].

\section{Effect of light}

As mentioned above, all experiments conducted in dark. Thus for investigation the effect of light on cell growth and carotenoid production, TBZ126 strain was incubated in the orbital shaker (Shaking Incubator VS-8480, Korea) under constant white fluorescent light (36Watt Dulux ${ }^{\bullet}$ fluorescent lamp) exposure in optimized conditions as obtained for cell growth and total carotenoid production. Therefore marine broth medium was constructed as $\mathrm{pH} 7.51$ and $\mathrm{NaCl}(\mathrm{w} / \mathrm{v})$ $18.33 \%$ for cell growth and $\mathrm{pH} 7.94$ and $\mathrm{NaCl}$ (w/v) $20 \%$ for carotenoid production. TBZ126 cultures were prepared with $10 \%$ inoculum and cultivated under continuous illumination from a 36-Watt Dulux lamp. The exposures to the incandescent lamp were made at a distance of approximately 35 centimeter.

The extracted pigments were separated by reversed-phase HPLC similar to that described in the previous paper [24] on an Agilent 1200 series HPLC system including a quaternary pump and a degasser equipped with a G1315B Diode Array Detector. HPLC analysis was performed using a Eurosphere RP-column (100-5 C18 column, 300×4.6 $\mathrm{mm}$ Knauer, Germany). The samples were eluted using a flow rate of $0.8 \mathrm{ml} / \mathrm{min}$. The mobile phase was acetonitrile-dichloromethane- methanol $(70: 20: 10 \mathrm{v} / \mathrm{v} / \mathrm{v}), 20 \mathrm{mM}$ ammonium acetate, and $0.1 \%$ triethylamine. The temperature was maintained at $20^{\circ} \mathrm{C}$, and UV detection was performed at $470 \mathrm{~nm}$. Both the extracts and standards were injected (injection volume: $20 \mu \mathrm{L}$ ) into the reverse-phase column. The experiment was conducted in triplicate. The mass spectra were recorded in the positive-ion mode in the mass range from 300 to 2000 $\mathrm{m} / \mathrm{z}$. The mass spectrometer parameters were set as follows: Nebulizer pressure was $40 \mathrm{psi}$, drying gas flow was $20 \mathrm{~L} / \mathrm{min}$, and gas temperature was $250^{\circ} \mathrm{C}$. The capillary voltage was $5000 \mathrm{~V}$. Ions were monitored in the scan mode. The identification of carotenoids was performed by comparing retention time, UV spectra, and the characteristics of the mass spectra (protonated molecule $\left([\mathrm{M}+\mathrm{H}]^{+}\right)$and its MS/MS fragments [24].

\section{Statistical analysis}

Statistical analysis of the data was performed using the Minitab 16.2.2 software (Minitab Inc., State College, PA, USA). The Statistica software (version 7.0, StatSoft, USA) was employed for the graphical optimization, respectively. Statistical testing of the model was done using Analysis of variance (ANOVA) to test the significance and adequacy of the model. Regression analysis was used to obtain the coefficients of a second-order polynomial. Data are reported as the average values of three independent experiments. Significance was determined at $p<0.05$.

\section{Results}

\section{Growth curve and determination of cell mass}

Growth curve of Halorubrum sp. TBZ126 is represented in Figure 1. As can be seen, growth rate was increased to a maximum after 9 days of incubation, followed by entrance to stationary phase (Figure 1). Accordingly, 9 days of incubation was being kept fixed in all experiments. Results of cell mass [dry cell weight (g DCW/l)] were included in Table 1.

\section{Optimization of the medium}

RSM was used to optimize environmental conditions (temperature, $\mathrm{pH}$ and salinity) for enhancing cell growth and total carotenoid production using a CCD. Cell growth $(\mathrm{g} / \mathrm{l})$ and total carotenoid production $(\mathrm{mg} / \mathrm{l})$ levels were recorded from each experiment. The CCD and the yields are shown in Table 1. The $p$ values were used to check the significance of each coefficient. Lack of fit was significant

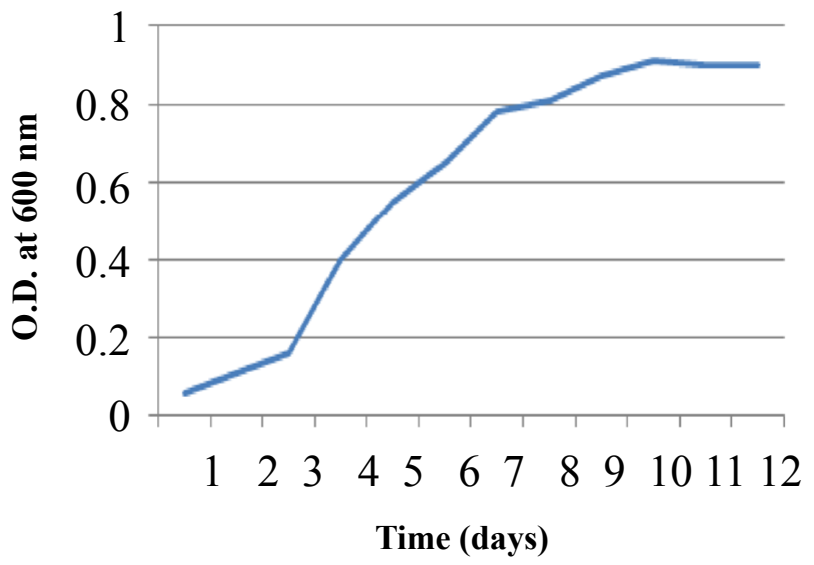

Figure 1: Growth curve of Halorubrum sp. TBZ126 in marine broth medium (temperature $30^{\circ} \mathrm{C}, \mathrm{pH} 7.5$ and $25 \%$ salinity). 


\begin{tabular}{|c|c|c|c|c|c|c|c|c|c|}
\hline \multicolumn{7}{|c|}{ Experimental variables } & \multicolumn{3}{|c|}{ Responses } \\
\hline \multirow[t]{2}{*}{ Run } & \multicolumn{2}{|c|}{$\mathbf{x}_{1}$ (temperature) } & \multicolumn{2}{|c|}{$\mathrm{x}_{2}(\mathrm{pH})$} & \multicolumn{2}{|c|}{$x_{3}$ (salinity) } & \multirow{2}{*}{$\begin{array}{l}\text { Biomass } \\
(\mathrm{g} / \mathrm{l})\end{array}$} & \multirow{2}{*}{$\begin{array}{l}\text { Volumetric Carotenoid } \\
(\mathrm{mg} / \mathrm{l})\end{array}$} & \multirow{2}{*}{$\begin{array}{c}\text { Cellular Carotenoid } \\
\qquad(\mathrm{mg} / \mathrm{g})\end{array}$} \\
\hline & Level & ${ }^{\circ} \mathrm{C}$ & Level & & Level & $\mathrm{NaCl}(\% \mathrm{w} / \mathrm{v})$ & & & \\
\hline 1 & -1 & 22 & 1 & 8.7 & 1 & 24.43 & 0.48 & 5.27 & 10.98 \\
\hline 2 & 0 & 32.5 & 0 & 7 & 0 & 16.25 & 0.82 & 10.1 & 12.32 \\
\hline 3 & -1 & 22 & -1 & 5.3 & -1 & 8.07 & 0.14 & 0.24 & 1.71 \\
\hline 4 & 0 & 32.5 & 1.68 & 10 & 0 & 16.25 & 0.42 & 10.53 & 25.07 \\
\hline 5 & 0 & 32.5 & 0 & 7 & 0 & 16.25 & 0.84 & 10.78 & 12.83 \\
\hline 6 & 1 & 43 & 1 & 8.7 & 1 & 24.43 & 0.56 & 5.28 & 9.43 \\
\hline 7 & -1 & 15 & 0 & 7 & 0 & 16.25 & 0.35 & 0.83 & 2.37 \\
\hline 8 & 0 & 32.5 & 0 & 7 & -1.68 & 30 & 0.53 & 9.91 & 18.7 \\
\hline 9 & 1 & 43 & 1 & 8.7 & -1 & 8.07 & 0.15 & 0.89 & 5.93 \\
\hline 10 & 1 & 43 & -1 & 5.3 & -1 & 8.07 & 0.04 & 0.19 & 4.75 \\
\hline 11 & 0 & 32.5 & 0 & 7 & 0 & 16.25 & 0.83 & 10.43 & 12.57 \\
\hline 12 & -1.68 & 50 & 0 & 7 & 0 & 16.25 & 0.09 & 0.24 & 2.67 \\
\hline 13 & 0 & 32.5 & 0 & 7 & -1.68 & 2.5 & 0.05 & 0.96 & 19.2 \\
\hline 14 & -1 & 22 & 1 & 8.7 & -1 & 8.07 & 0.14 & 1.03 & 7.36 \\
\hline 15 & -1 & 22 & -1 & 5.3 & 1 & 24.43 & 0.13 & 1.32 & 10.15 \\
\hline 16 & 0 & 32.5 & 0 & 7 & 0 & 16.25 & 0.84 & 10.78 & 12.83 \\
\hline 17 & 0 & 32.5 & 0 & 7 & 0 & 16.25 & 0.83 & 10.53 & 12.69 \\
\hline 18 & 0 & 32.5 & -1.68 & 4 & 0 & 16.25 & 0.04 & 0.15 & 3.75 \\
\hline 19 & 1 & 43 & -1 & 5.3 & 1 & 24.43 & 0.12 & 1.1 & 9.17 \\
\hline 20 & 0 & 32.5 & 0 & 7 & 0 & 16.25 & 0.84 & 10.78 & 12.83 \\
\hline
\end{tabular}

Table 1: Central composite design (CCD) matrix (Experimental variables and responses).

\begin{tabular}{|c|c|c|c|c|c|}
\hline Source of variation & $\mathrm{DF}^{1)}$ & $\begin{array}{l}\text { Sum of } \\
\text { squares }\end{array}$ & $\begin{array}{l}\text { Mean } \\
\text { square }\end{array}$ & F-value & $p$-value \\
\hline \multicolumn{6}{|c|}{ The model for biomass production $\left(Y_{1}\right)^{2)}$} \\
\hline Regression & 9 & 1.98 & 0.22 & 89.59 & 0 \\
\hline Linear & 3 & 0.38 & 0.16 & 66.86 & 0 \\
\hline Square & 3 & 1.53 & 0.51 & 207.81 & 0 \\
\hline Interaction & 3 & 0.07 & 0.02 & 8.97 & 0.003 \\
\hline Residual error & 10 & 0.02 & 0 & & \\
\hline Lack-of-fit & 5 & 0.02 & 0 & 72.6 & 0 \\
\hline Pure error & 5 & 0 & 0 & & \\
\hline Total & 19 & 2 & & & \\
\hline Model terms & Coefficient & DF & $\begin{array}{l}\text { Standard } \\
\text { error }\end{array}$ & $t$-value & $p$-value \\
\hline Intercept & -4.75 & 1 & 0.38 & -12.62 & 0 \\
\hline$x_{1}$ (temperature) & 0.11 & 1 & 0.01 & 10.37 & 0 \\
\hline $\mathrm{x}_{2}(\mathrm{pH})$ & 0.85 & 1 & 0.07 & 12.51 & 0 \\
\hline$x_{3}$ (salinity) & 0.06 & 1 & 0.01 & 4.66 & 0.001 \\
\hline $\begin{array}{l}\mathrm{x}_{1}^{2} \text { (temperature }{ }^{*} \\
\text { temperature) }\end{array}$ & -0.002 & 1 & 0 & -16.47 & 0 \\
\hline $\mathrm{x}_{2}^{2}(\mathrm{pH} * \mathrm{pH})$ & -0.07 & 1 & 0.004 & -16.2 & 0 \\
\hline $\mathrm{x}_{3}^{2}$ (salinity ${ }^{*}$ salinity $)$ & -0.003 & 1 & 0 & -14.56 & 0 \\
\hline $\mathrm{x}_{1} \mathrm{x}_{2}$ (temperature $\left.{ }^{*} \mathrm{pH}\right)$ & 0.001 & 1 & 0 & 1.43 & 0.184 \\
\hline $\begin{array}{c}\mathrm{x}_{1} \mathrm{x}_{3} \text { (temperature * } \\
\text { salinity) }\end{array}$ & 0 & 1 & 0 & 1.14 & 0.28 \\
\hline $\mathrm{x}_{2} \mathrm{x}_{3}\left(\mathrm{pH}{ }^{*}\right.$ salinity $)$ & 0.006 & 1 & 0.001 & 4.85 & 0.001 \\
\hline
\end{tabular}

1) Degree of freedom

2) $R^{2}=98.77 \%$ and adjusted $R^{2}\left(R^{2}{ }_{\text {adj }}\right)=97.67 \%$

Table 2: Analysis of variance (ANOVA) for biomass production by Halorubrum sp. TBZ126.

at the $95 \%$ level $(p<0.05)$. The models were then applied to statistical analysis (ANOVA) to neglect all terms that were statistically nonsignificant $(p>0.05)$ (Tables 2 and 3 ). The reduced equations were expressed as follows:

$\mathrm{Y}_{1}=-4.75+0.11 \mathrm{x}_{1}+0.85 \mathrm{x}_{2}+0.06 \mathrm{x}_{3}-0.002\left(\mathrm{x}_{1}\right)^{2}-0.07\left(\mathrm{x}_{2}\right)^{2}-$ $0.003\left(\mathrm{x}_{3}\right)^{2}+0.006 \mathrm{x}_{2} \mathrm{x}_{3}$

\begin{tabular}{|c|c|c|c|c|c|}
\hline Source of variation & $D^{1}{ }^{1}$ & $\begin{array}{l}\text { Sum of } \\
\text { squares }\end{array}$ & $\begin{array}{c}\text { Mean } \\
\text { square }\end{array}$ & F-value & $p$-value \\
\hline \multicolumn{6}{|c|}{ The model for total carotenoid production $\left(\mathrm{Y}_{2}\right)^{2)}$} \\
\hline Regression & 9 & 405.65 & 45.07 & 17.03 & 0 \\
\hline Linear & 3 & 107.37 & 40.55 & 15.32 & 0 \\
\hline Square & 3 & 292.9 & 97.63 & 36.89 & 0 \\
\hline Interaction & 3 & 5.39 & 1.8 & 0.68 & 0.585 \\
\hline Residual error & 10 & 26.79 & 2.65 & & \\
\hline Lack-of-fit & 5 & 30.47 & 5.22 & 69.71 & 0 \\
\hline Pure error & 5 & 0.37 & 0.07 & & \\
\hline Total & 19 & 432.12 & & & \\
\hline Model terms & Coefficient & DF & $\begin{array}{c}\text { Standard } \\
\text { error }\end{array}$ & t-value & $p$-value \\
\hline Intercept & -72.31 & 1 & 12.37 & -5.85 & 0 \\
\hline $\mathrm{x}_{1}$ (temperature) & 2.27 & 1 & 0.36 & 6.38 & 0 \\
\hline $\mathrm{x}_{2}(\mathrm{pH})$ & 9.54 & 1 & 2.24 & 4.24 & 0.002 \\
\hline $\mathrm{x}_{3}$ (salinity) & 0.85 & 1 & 0.41 & 2.06 & 0.066 \\
\hline $\begin{array}{l}\mathrm{x}_{1}^{2} \text { (temperature* } \\
\text { temperature) }\end{array}$ & -0.03 & 1 & 0 & -9.007 & 0 \\
\hline $\mathrm{x}_{2}^{2}\left(\mathrm{pH}{ }^{*} \mathrm{pH}\right)$ & -0.68 & 1 & 0.13 & -5.04 & 0.001 \\
\hline $\mathrm{x}_{3}^{2}($ salinity *salinity) & -0.03 & 1 & 0 & -4.72 & 0.001 \\
\hline $\mathrm{x}_{1} \mathrm{x}_{2}$ (temperature $\left.{ }^{*} \mathrm{pH}\right)$ & 0.005 & 1 & 0.03 & 0.17 & 0.867 \\
\hline $\begin{array}{l}x_{1} x_{3} \text { (temperature } \\
\text { *salinity) }\end{array}$ & 0 & 1 & 0 & -0.07 & 0.948 \\
\hline $\mathrm{x}_{2} \mathrm{x}_{3}\left(\mathrm{pH}^{*}\right.$ salinity $)$ & 0.05 & 1 & 0.04 & 1.41 & 0.188 \\
\hline
\end{tabular}

1) Degree of freedom

2) $R^{2}=93.87 \%$ and adjusted $R^{2}\left(R^{2}{ }_{\text {adj }}\right)=88.36 \%$

Table 3: Analysis of variance (ANOVA) for total carotenoid production by Halorubrum sp. TBZ126.

$$
\mathrm{Y}_{2}=-72.32+2.28 \mathrm{x}_{1}+9.54 \mathrm{x}_{2}+0.85 \mathrm{x}_{3}-0.04\left(\mathrm{x}_{1}\right)^{2}-0.68\left(\mathrm{x}_{2}\right)^{2}-0.03\left(\mathrm{x}_{3}\right)^{2}
$$

Where $Y_{1}$ and $Y_{2}$ are the predicted response for biomass $(g / l)$ the total carotenoid content $(\mathrm{mg} / \mathrm{l})$ respectively and the coefficients are obtained from regression analysis. The central composite design and the yields are shown in Table 1 . The $p$ values were used to check the significance of each coefficient which, in turn, was necessary to understand the pattern of the mutual interactions between the 
test variables. The smaller the $p$-value, the more significant was the corresponding coefficient. Lack of fit was not significant at the $5 \%$ level $(p>0.05)$.

The estimated coefficients and the corresponding $p$ values indicate that $\mathrm{X}_{1}$ (Temperature), $\mathrm{X}_{2}(\mathrm{pH})$ and $\mathrm{X}_{3}$ (salinity) were significant terms for both cell growth and carotenoid production. By substitution of factor levels into the regression equation, the maximum predictable response for biomass and total carotenoid production was calculated and experimentally verified.

According to CCD results, temperature $31^{\circ} \mathrm{C}$ and $32^{\circ} \mathrm{C}, \mathrm{pH} 7.51$ and 7.94 , and $18.33 \%$ and $20.55 \%$ salinity were the optimum conditions for cell growth and total carotenoid production, respectively, by Halorubrum sp. TBZ126 with a confidence level of 95\% (at level $\alpha=0.05)$. Based on the statistical analysis, only the interaction between $\mathrm{pH}$ and salinity had significant effect $(p<0.05)$ on cell growth. The

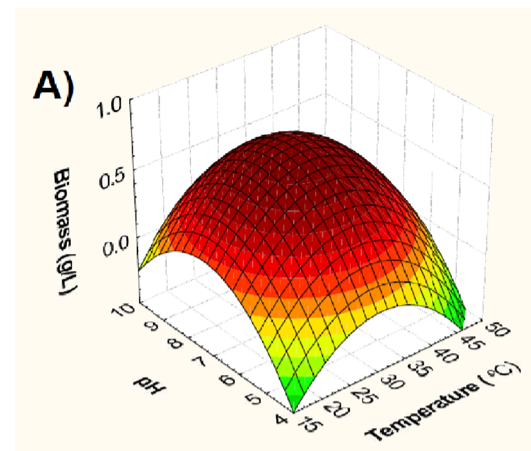

B)
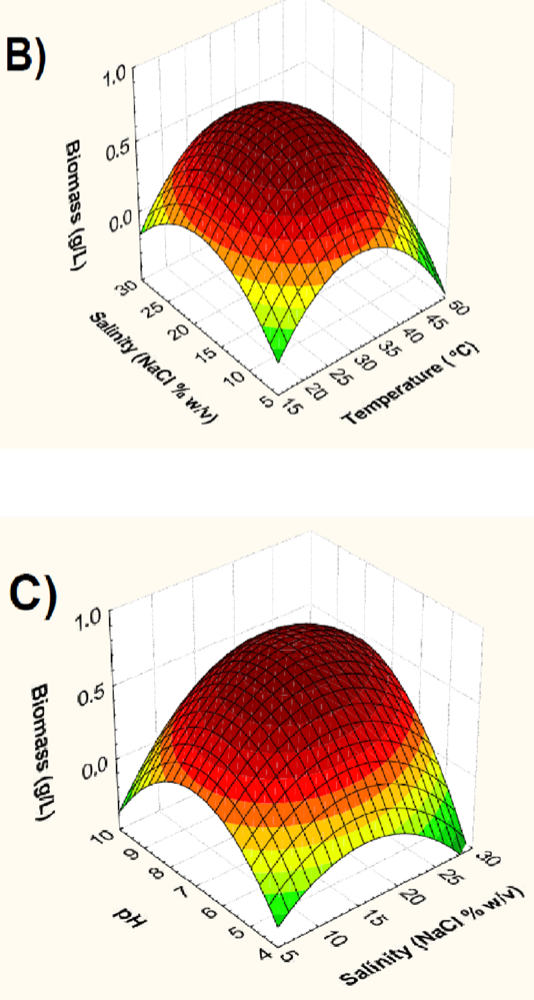

Figure 2: The 3D-surface plots for biomass production by Halorubrum $\mathrm{sp}$. TBZ126. The interaction between (A) $\mathrm{pH}$ and temperature, (B) salinity and temperature and $(\mathrm{C})$ salinity and $\mathrm{pH}$.

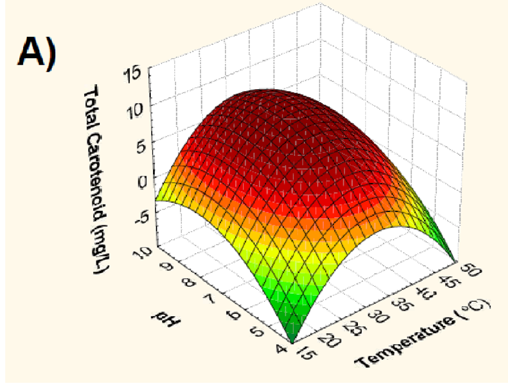

B)

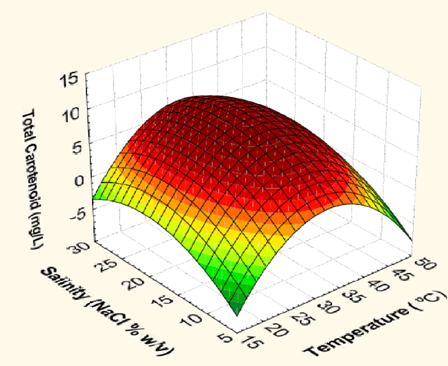

C)

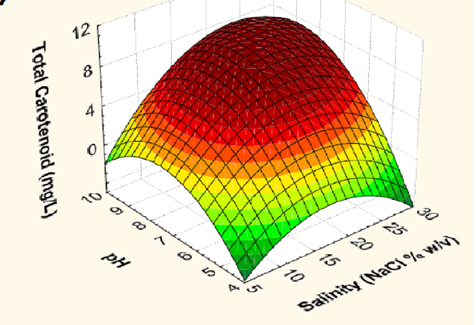

Figure 3: The 3D-surface plots for total carotenoid production by Halorubrum sp. TBZ126. The interaction between (A) pH and temperature, (B) salinity and temperature and $(\mathrm{C})$ salinity and $\mathrm{pH}$.

3D-surface plots representing the interaction effects of all independent variable on biomass and total carotenoid production are shown in Figures 2 and 3 respectively.

\section{Validation of the optimal conditions}

CCD based experimental results showed that the optimum conditions for biomass and carotenoid production were $31^{\circ} \mathrm{C}$ and $32^{\circ} \mathrm{C}$, pH 7.51 and 7.94 , and $18.33 \%$ and $20.55 \%$ salinity, respectively. To assess the validity of the predicted optimum conditions, additional series of batch trials in 3 replicates were conducted. Experimental results indicated that the highest biomass $(0.9 \pm 0.01 \mathrm{~g} / \mathrm{l})$ and carotenoid production $(11.71 \pm 0.01 \mathrm{mg} / \mathrm{l})$ are obtained at the predicted points. Additionally, the biomass and total carotenoid content obtained from the experiments are very close to those estimated using RSM $(0.87 \mathrm{~g} / \mathrm{l}$ and $11.69 \mathrm{mg} / \mathrm{l}$ ) at the optimal conditions. The good agreement between the experimental and estimated responses verifies the existence of maximum points and the accuracy of the mathematical models.

\section{Effect of light}

Total carotenoid and biomass increased in cells grown under light 
exposure in optimized condition for cell growth and total carotenoid production when compared with that of cells grown under dark (Table 4). The carotenoids were extracted from the cells of TBZ126 strain and the main compounds were measured by HPLC. The results (Figures 4 and 5) showed that the main carotenoids were identified as bacterioruberin, lycopene and $\beta$-carotene, which contents in total carotenoids were $96.65 \%, 1.36 \%$ and $1.99 \%$, respectively, in optimized condition for cell growth and $98.01 \%, 0.89 \%$ and $1.1 \%$, respectively, in optimized condition for total carotenoid production.

\section{Discussion}

The production of carotenoids from biological sources has been an area of extensive investigation in the last decade. Carotenoids have significant commercial interests, which are used as coloring agents in neutraceuticals, pharmaceuticals, cosmetics and foods [13,20,28]. In the present study the CCD was applied to find the optimal level of various factors including temperature, $\mathrm{pH}$ and salinity in order to improve cell growth and total carotenoid production of Halorubrum sp. TBZ126. In addition the effect of illumination on cell growth and total carotenoid production in optimized condition was studied.

Based on the results of the design, temperature $31^{\circ} \mathrm{C}$ and $32^{\circ} \mathrm{C}$, $\mathrm{pH} 7.51$ and 7.94 and $\mathrm{NaCl}(\mathrm{w} / \mathrm{v}) \quad 18.33 \%$ and $20.55 \%$ were the optimum conditions for cell growth and total carotenoid production respectively, by Halorubrum sp. TBZ126. The maximum yields were demonstrated by confirmatory experiment of the optimal medium in 9 days incubation that the predicted values agreed with the experimental values well. The interaction effects of $\mathrm{pH}$ and temperature on biomass production are shown in Figure 2a. As seen, temperature and $\mathrm{pH}$ value elevation up to the optimum point increased the biomass production to a maximum level. However, the trend reversed following further increase in temperature and $\mathrm{pH}$. This observation can be seen for the effects of salinity and temperature (Figure $2 \mathrm{~b}$ ), salinity and $\mathrm{pH}$ (Figure 2c) on biomass production by Halorubrum sp. TBZ126. The same behavior was observed for carotenoid production with regard to variation in temperature and $\mathrm{pH}$, temperature and salinity and also for $\mathrm{pH}$ and salinity as illustrated in Figure 3. The Figures show that the maximum point for both biomass and carotenoid production is located inside the experimental region. In addition, according to the shape of all plots, maximum points (i.e. optimum conditions) are located inside the experimental regions implying accuracy of the experiments [29].

The effect of environmental factors such as temperature, $\mathrm{pH}$ and salinity of the culture medium in the production of total carotenoids and biomass by various microorganisms was evaluated by other authors [30-37].

Temperature is one of the most important environmental factors affecting the growth of microorganisms. It causes changes in many biosynthetic pathways, such as carotenoid biosynthesis [31]. Many of

\begin{tabular}{|c|c|c|c|c|}
\hline & \multicolumn{2}{|c|}{ Under light conditions } & \multicolumn{2}{c|}{ Under dark conditions } \\
\cline { 2 - 4 } & Growth optimum & Carotenoid optimum & Growth optimum \\
\hline Total carotenoids (mg/l) (Mean \pm SD) & $11.39 \pm 0.11$ & $16.35 \pm 0.01$ & $8.15 \pm 0.02$ \\
\hline Biomass $(\mathrm{g} / \mathrm{l})($ Mean \pm SD) & $2.13 \pm 0.006$ & $2.17 \pm 0.01$ & $0.82 \pm 0.01$ \\
\hline
\end{tabular}

Table 4: Effect of illumination on the biomass $(\mathrm{g} / \mathrm{l})$ and total carotenoid production by Halorubrum sp. TBZ126.

A)

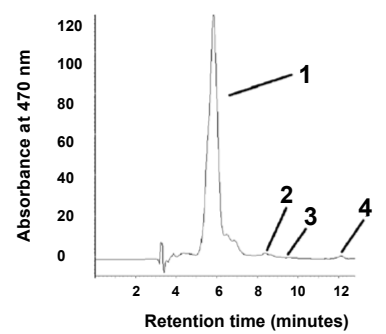

B)

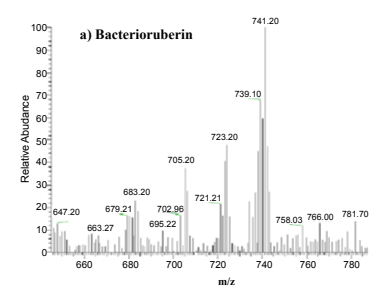

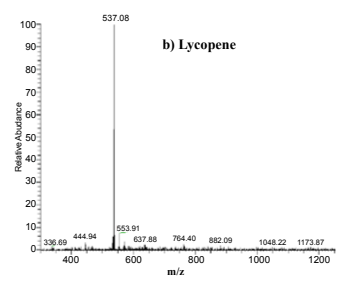

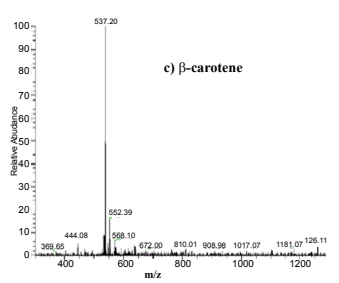

C)

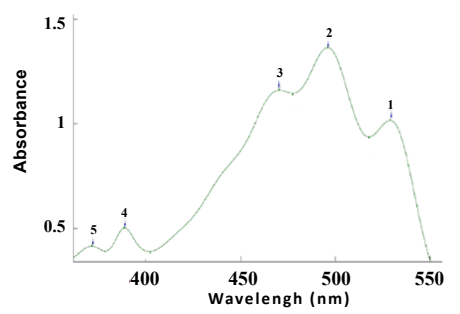

Figure 4: A) Reverse-phase liquid chromatography of the major carotenoids of Halorubrum sp. TBZ126 in optimized condition for cell growth under light. Column: 100-5 C18 column (300 by $4.6 \mathrm{~mm}$, Knauer, Germany). Eluent: acetonitrile-dichloromethane-methanol (70:20:10 v/v/v), $20 \mathrm{mM}$ ammonium acetate, and 0.1\% triethylamine. Flow rate: $0.8 \mathrm{ml} / \mathrm{min}$. Detection: $470 \mathrm{~nm}$. Peak identities: peak 1, bacterioruberin; peak 2, all-trans-lycopene; peaks 3, 13-cis-lycopene; peak 4, alltrans- $\beta$-carotene. B) Mass spectra (ESI mode) of major carotenoids fractions from Halorubrum sp. TBZ126. Bacterioruberin (a), lycopene (b) and $\beta$-carotene (c). C) UV-VIS spectrum of total carotenoid extract from Halorubrum sp. TBZ126 in optimized condition for cell growth under light with typical characteristics of three fingered $(1,2$ and 3$)$ and two cis maxima (4 and 5) which corresponded to bacterioruberin [24]. 
A)

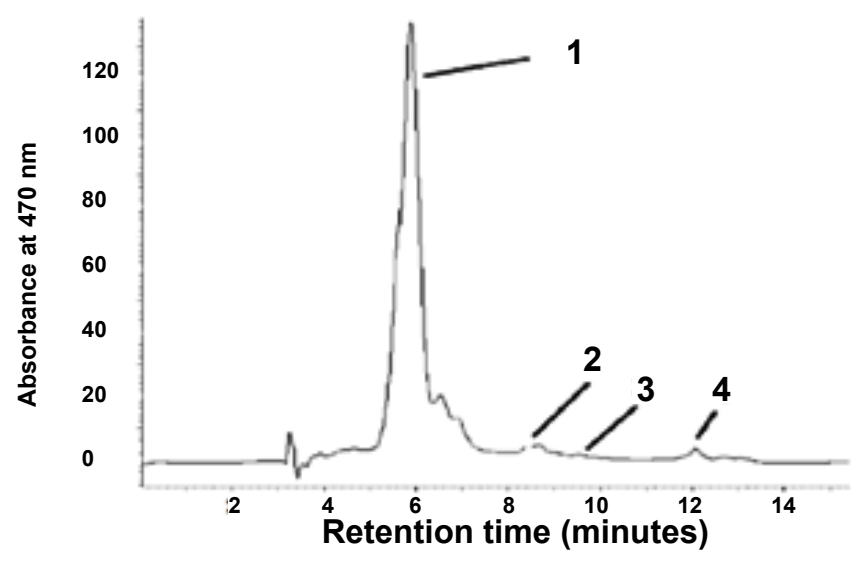

B)

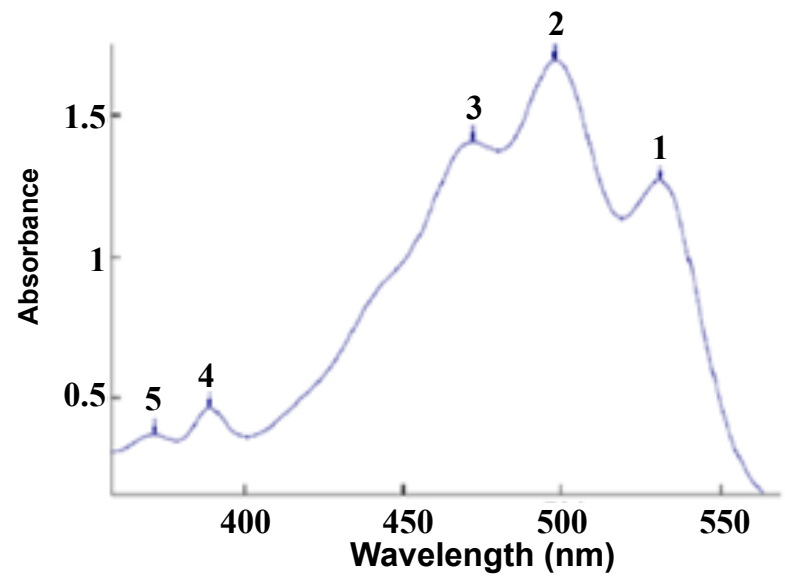

Figure 5: A) Reverse-phase liquid chromatography of the major carotenoids of Halorubrum sp. TBZ126 in carotenoid production optimized condition and under light exposure. Column: 100-5 C18 column (300 by $4.6 \mathrm{~mm}$, Knauer, Germany). Eluent: acetonitrile-dichloromethane-methanol (70:20:10 v/v/v), $20 \mathrm{mM}$ ammonium acetate and $0.1 \%$ triethylamine with flow rate of $0.8 \mathrm{ml} / \mathrm{min}$ and detection at $470 \mathrm{~nm}$. Peak identities: peak 1, bacterioruberin; peak 2, all-trans-lycopene; peaks 3 , 13-cis-lycopene; peak 4, all-trans-ß-carotene. B) UV-VIS spectrum of the total carotenoid extract from Halorubrum sp. TBZ126 in optimized condition for carotenoid production and under light exposure with typical characteristics of three fingered $(1,2 \& 3)$ and two cis maxima (4 \& 5) maximum absorbance.

the extremely halophilic archaea are mesophilic or neutrophilic and minor group of them have temperature optima of $50^{\circ} \mathrm{C}$ or greater [38]. Biomass and total carotenoid production by Halorubrum sp. TBZ126 occurred in the range of 15 to $50^{\circ} \mathrm{C}$ with optimum point at about $32^{\circ} \mathrm{C}$. The ability of Halorubrum sp. TBZ126 to grow and produce carotenoids at higher temperatures, for example, over $32^{\circ} \mathrm{C}$, is regarded as a positive point to its industrial application because it reduces the cooling cost.

The $\mathrm{pH}$ of growth medium was another important factor, affecting the biomass and total carotenoid production by Halorubrum sp., TBZ126. It has been reported that $\mathrm{pH}$ significantly influences cell growth and total carotenoid production in a lot of microorganism [7]. Most of the extremely halophilic archaea display optimum growth in $\mathrm{pH}$ values near 7. Halorubrum chaviator, which has $100 \% 16 \mathrm{~S}$ rRNA sequence similarity with Halorubrum sp. TBZ126, grows optimally at $\mathrm{pH}$ of 7.4. A small group of the validly published extremely halophilic archaea show optimum growth in $\mathrm{pH}$ of 8.5 or greater, and therefore are considered as haloalkaliphiles [38]. In the present work, the biomass and total carotenoid production by Halorubrum sp. TBZ126 occurred between $\mathrm{pH} 7$ and 10. It is found that biomass and total carotenoid production in $\mathrm{pH} 10$ was about $93 \%$ and $90 \%$ respectively, compared to data reached from optimum conditions.

Concentration of $\mathrm{NaCl}$ was the third and most important factor affecting cell growth and total carotenoid production by TBZ126. It has been found that the $\mathrm{NaCl}$ concentration is the most important factor in determining halobacterial growth. In addition, it has also been found that the $\mathrm{NaCl}$ requirement for halobacterial growth is specific and $\mathrm{NaCl}$ cannot be replaced by other solutes [39]. In the present study biomass and total carotenoid production by Halorubrum sp. TBZ126 found in the range of 2.5 to $30 \% \mathrm{NaCl}(\mathrm{w} / \mathrm{v})$ with optimum point in $18.33 \%$ and $20.55 \%$ respectively. As can be seen from Figures 2 and 3 and Table 1, in the same condition of $\mathrm{pH}$ and temperature, maximum production of carotenoid was estimated near center point of design (i.e., $16.25 \%$ ).
Experimental based predicted optimum point derived from analysis with Minitab software was calculated as $20.55 \% \mathrm{NaCl}$. It means that the maximum carotenoid production point was very close to estimated point and both of the points are lower than $30 \%$ meaning that maximum total carotenoid production is obtained in less than $30 \% \mathrm{NaCl}$; i.e. in $20.55 \% \mathrm{NaCl}$. These results are in agree with previous studies $[40,41]$ reporting elevation in synthesis of bacterioruberin by haloarchaea in response to stress caused by low concentrations of $\mathrm{NaCl}$. In the other hand similar to Haloferax mediterranei [40], Halorubrum sp. TBZ126 has ability to survive when the salt concentration falls below $10 \%$; but unlike $H$. mediterranei which doesn't produce carotenoid in $5 \% \mathrm{NaCl}$ [40] unless magnesium sulfate concentration increases from $2 \%$ to $8 \%$ [41], our isolate can produce carotenoids in $2.5 \% \mathrm{NaCl}$ in the absence of sodium acetate and without any increase in magnesium sulfate concentration $(0.324 \%)$.

Light is an important factor to considerate during the production of microbial carotenoids; hence, it improves carotenogenesis. Microorganisms need to prevent themselves from the light that causes damage, and carotenogenesis is a photoprotective mechanism [42]. Our study indicates that Halorubrum sp. TBZ126 synthesize higher amounts of biomass and total carotenoids in the light than in the dark. Using optimization with RSM and light as an inducing factor in this study, total carotenoid production showed $45 \%$ increase compared to the un-optimized medium reported previously [24].

\section{Conclusions}

In conclusion the present study reports a considerable increase in pigmentation of TBZ126 following optimization of the factors using RSM where $45 \%$ elevation was observed in pigmentation compared to general condition. The main produced carotenoid was found to be bacterioruberin. Although, the optimum conditions for maximum production of total carotenoids differ from optimum points for 
maximum biomass production, however, the optimal levels of the 3 major growth medium factors for cell growth are very close to those of carotenoid biosynthesis. TBZ126, which is naturally adapted to higher $\mathrm{NaCl}$ concentrations (about 20\%), could produce carotenoids at lower concentrations of $\mathrm{NaCl}$ (as low as 2.5\%), without elevating magnesium sulfate concentration and supplementation of sodium acetate. There should be many other factors affecting pigmentation of TBZ126 such as shaker speed, type and concentration of nutrient components. A thorough understanding of the regulation and pathway of pigment production will allow us to develop defined bioprocess for enhanced production of the desired pigment especially bacterioruberin.

\section{References}

1. Netzer R, Stafsnes MH, Andreassen T, Goksøyr A, Bruheim P, et al. (2010) Biosynthetic Pathway for $\mathrm{Y}$-Cyclic Sarcinaxanthin in Micrococcus luteus: Heterologous Expression and Evidence for Diverse and Multiple Catalytic Functions of C50 Carotenoid Cyclases. J Bacteriol 192: 5688-5699.

2. Jaswir I, Noviendri D, Hasrini RF, Octavianti F (2011) Carotenoids: Sources, medicinal properties and their application in food and nutraceutical industry. $J$ Med Plants Res 5: 7119-7131.

3. Sandmann G (2003) Combinatorial biosynthesis of novel carotenoids in E. coli. In: E. coli Gene Expression Protocols. Humana Press Inc., Totowa.

4. Schmidt-Dannert C (2000) Engineering novel carotenoids in microorganisms. Curr Opin Biotechnol 11: 255-261.

5. Asker D, Awad TS, Beppu T, Ueda K (2012) Isolation, characterization, and diversity of novel radiotolerant carotenoid-producing bacteria. Methods Mol Biol 892: 21-60.

6. El-Banna AAE-R, El-Razek AMA, El-Mahdy AR (2012) Isolation, identification and screening of carotenoid-producing strains of Rhodotorula glutinis. Food Nutr 3: 627-633.

7. Raghavan T, Furtado I (2004) Occurrence of extremely halophilic Archaea in sediments from the continental shelf of west coast of India. Curr Sci 86: 10651067.

8. Emerson D, Chauhan S, Oriel P, Breznak JA (1994) Haloferax sp. D1227, a halophilic Archaeon capable of growth on aromatic compounds. Arch Microbiol 161: 445-452.

9. Oren A, Rodríguez-Valera F (2001) The contribution of halophilic Bacteria to the red coloration of saltern crystallizer ponds(1). FEMS Microbiol Ecol 36: 123130.

10. Mohebbi F, Ahmadi R, Azari AM, Esmaili L, Asadpour Y (2011) On the red coloration of Urmia Lake (Northwest Iran). Int J Aqu Sci 2: 88-92.

11. Hammond BR Jr, Renzi LM (2013) Carotenoids. Adv Nutr 4: 474-476.

12. Abbes M, Baati H, Guermazi S, Messina C, Santulli A, et al. (2013) Biological properties of carotenoids extracted from Halobacterium halobium isolated from a Tunisian solar saltern. BMC Complement Altern Med 13: 255.

13. Kirti K, Amita S, Priti S, Mukesh Kumar A, Jyoti S (2014) Colorful World of Microbes: Carotenoids and Their Applications. Adv Biol 2014: 1-13.

14. Kullavanijaya P, Lim HW (2005) Photoprotection. J Am Acad Dermatol 52: $937-$ 958

15. Barth MM, Zhou C, Kute KM, Rosenthal GA (1995) Determination of optimum conditions for supercritical fluid extraction of carotenoids from carrot (Daucus carota L.) tissue. J Agric Food Chem 43: 2876-2878.

16. Britton $G$ (1995) Structure and properties of carotenoids in relation to function. FASEB J 9: 1551-1558.

17. Jothi D (2008) Extraction of natural dyes from African marigold flower (Tagetes ereectal) for textile coloration. Autex Res J 8: 49-53.

18. Vernon-Carter EJ, Ponce-Palafox JT, Pedroza-Islas R (1996) Pigmentation of Pacific white shrimp (Penaeus vannamei) using Aztec marigold (Tagetes erecta) extracts as the carotenoid source. Arch Latinoam Nutr 46: 243-246.

19. Breithaupt DE, Wirt U, Bamedi A (2002) Differentiation between lutein monoester regioisomers and detection of lutein diesters from marigold flowers (Tagetes erecta L.) and several fruits by liquid chromatography-mass spectrometry. J Agric Food Chem 50: 66-70.
20. Rad FA, Aksoz N, Hejazi MA (2011) Effect of salinity on cell growth and ß-carotene production in Dunaliella sp. isolates from Urmia Lake in northwest of Iran. Afr J Biotechnol 10: 2282-2289.

21. Cabral MMS, Cence K, Zeni J, Tsai SM, Durrer A, et al. (2011) Carotenoids production from a newly isolated Sporidiobolus pararoseus strain by submerged fermentation. Eur Food Res Technol 233: 159-166.

22. Squina F, Yamashita F, Pereira1 J, Mercadante A (2002) Production of carotenoids by Rhodotorula rubra and $\mathrm{R}$. glutinis in culture medium supplemented with sugar cane juice. Food Biotechnol 16: 227-235.

23. Nasri Nasrabadi MR, Razavi SH (2010) Use of response surface methodology in a fed-batch process for optimization of tricarboxylic acid cycle intermediates to achieve high levels of canthaxanthin from Dietzia natronolimnaea HS-1. J Biosci Bioeng 109: 361-368.

24. Naziri D, Hamidi M, Hassanzadeh S, Tarhriz V, Maleki Zanjani B, et al. (2014) Analysis of Carotenoid Production by Halorubrum sp. TBZ126; an Extremely Halophilic Archeon from Urmia Lake. Adv Pharm Bull 4: 61-67.

25. Debelius B, Gómez-Parra A, Forja J (2009) Oxygen solubility in evaporated seawater as a function of temperature and salinity. Hydrobiologia 632: 157-165.

26. Pal Y, Khushoo A, Mukherjee KJ (2006) Process optimization of constitutive human granulocyte-macrophage colony-stimulating factor (hGM-CSF) expression in Pichia pastoris fed-batch culture. Appl Microbiol Biotechnol 69: 650-657.

27. Monica M, Dan MI, Vasile J, Clemens $P$ (2003) Influence of cultivation media on halobacteria I. Growth and biomass formation. AUCFT 7: 17-24.

28. Álvarez R, Vaz B, Gronemeyer H, de Lera ÁR (2014) Functions, therapeutic applications, and synthesis of retinoids and carotenoids. Chem Rev 114: 1-125.

29. Bezerra MA, Santelli RE, Oliveira EP, Villar LS, Escaleira LA (2008) Response surface methodology (RSM) as a tool for optimization in analytical chemistry. Talanta 76: 965-977.

30. Razavi SH, Marc I, Blanchard F, Lefloch F, Tessier B, et al. (2006) Effect of temperature and $\mathrm{pH}$ on the growth kinetics and carotenoid production by Sporobolomyces ruberrimus $\mathrm{H} 110$ using technical glycerol as carbon source. Iran J Chem Chem Eng Research Note Vol 25: 59-64.

31. Khodaiyan F, Razavi SH, Emam-Djomeh Z, Mousavi SM (2007) Optimization of canthaxanthin production by Dietzia natronolimnaea HS-1 using response surface methodology. Pak J Biol Sci 10: 2544-2552.

32. Liu YS, Wu JY (2007) Optimization of cell growth and carotenoid production of Xanthophyllomyces dendrorhous through statistical experiment design. Biochem Eng J 36: 182-189.

33. Nasrabadi MRN, Razavi SH (2011) Optimization of ß-carotene production by a mutant of the lactose-positive yeast Rhodotorula acheniorum from whey ultrafiltrate. Food Sci Biotechnol 20: 445-454.

34. Zhang Z, Zhang X, Tan T (2014) Lipid and carotenoid production by Rhodotorula glutinis under irradiation/high-temperature and dark/low-temperature cultivation. Bioresour Technol 157: 149-153.

35. Hagi T, Kobayashi M, Nomura M (2014) Aerobic condition increases carotenoid production associated with oxidative stress tolerance in Enterococcus gilvus. FEMS Microbiol Lett 350: 223-230.

36. Campenni' L, Nobre BP, Santos CA, Oliveira AC, Aires-Barros MR, et al. (2013) Carotenoid and lipid production by the autotrophic microalga Chlorella protothecoides under nutritional, salinity, and luminosity stress conditions. App Microbiol Biotechnol 97: 1383-1393.

37. Binti Ibnu Rasid EN, Mohamad SE, Jamaluddin H, Salleh MM (2014) Screening factors influencing the production of astaxanthin from freshwater and marine microalgae. Appl Biochem Biotechnol 172: 2160-2174.

38. Bowers KJ, Wiegel J (2011) Temperature and pH optima of extremely halophilic archaea: a mini-review. Extremophiles 15: 119-128.

39. Zeng C, Zhu J-C, Liu Y, Yang Y, Zhu J-Y, et al. (2006) Investigation of the influence of $\mathrm{NaCl}$ concentration on Halobacterium salinarum growth. $\mathrm{J}$ Therm Anal Calorim 84: 625-630.

40. D'Souza SE, Altekar W, D'Souza SF (1997) Adaptive response of Haloferax mediterranei to low concentrations of $\mathrm{NaCl}(<20 \%)$ in the growth medium. Arch Microbiol 168: 68-71. 
Citation: Hamidi M, Abdin MZ, Nazemyieh H, Hejazi MA, Hejazi MS (2014) Optimization of Total Carotenoid Production by Halorubrum Sp. TBZ126 Using Response Surface Methodology. J Microb Biochem Technol 6: 286-294. doi:10.4172/1948-5948.1000158

41. Fang CJ, Ku KL, Lee MH, Su NW (2010) Influence of nutritive factors on C50 carotenoids production by Haloferax mediterranei ATCC 33500 with two-stage cultivation. Bioresour Technol 101: 6487-6493.
42. Mata-Gómez LC, Montañez JC, Méndez-Zavala A, Aguilar CN (2014) Biotechnological production of carotenoids by yeasts: an overview. Microb Cell Fact 13: 12 